\title{
D D Cunningham and the Aetiology of Cholera in British India, 1869-1897
}

\author{
JEREMY D ISAACS*
}

In a country like India, so many "fountains of immortal bliss" lie open to everyone in the observation and record of events of daily occurrence that it seems to be almost a duty for any one who has realised how copious and unfailing they are, to do his best to make them known to others, however conscious he may be of his inability to do so in an attractive and adequate fashion. ${ }^{1}$

Cholera in the nineteenth century has proved an enduring topic for historians. In 1961 Asa Briggs called for analysis of cholera as an under-utilized yet potentially powerful tool for the emerging discipline of social history. ${ }^{2}$ Researchers in the field responded with a plethora of works on this most brutal of epidemic diseases. Despite methodological and interpretative differences, the literature has until recently been dominated by accounts of cholera in Europe and North America. ${ }^{3}$ The discovery by the German bacteriologist Robert Koch (1843-1910) of the cholera bacillus in Calcutta in 1884 is one of the central events in the history of cholera, yet Western historians have been slow to discuss the Indian cholera story in any depth. Only recently have medical historians such as David Arnold and Mark Harrison begun reconstructing the role of India and Anglo-Indians in the world-wide discourse generated by epidemic diseases including cholera. ${ }^{4}$

The object of this study is to investigate further the Indian cholera story, before and after Koch's discovery of the cholera vibrio. My focus is David Douglas Cunningham (1843-1914), a Scottish doctor in the Indian Medical Service, who from 1869 to 1897 was a scientific assistant to the Sanitary Commissioner with the Government of India. Working

*Jeremy D Isaacs, BA, 47 Llanvanor Road, London NW2 2AR.

I would like to thank Dr Mark Weatherall for guiding me through the early development of this paper and my friends and colleagues in Cambridge and London who offered advice and support during its preparation.

1 D D Cunningham, Some Indian friends and acquaintainces, London, John Murray, 1903, p. 8.

2 A Briggs, 'Cholera and society in the nineteenth century', Past and Present, 1961, 19: 76-96.

${ }^{3}$ For Europe see, N Longmate, King Cholera: the biography of a disease, London, $\mathrm{H}$ Hamilton, 1966; R E McGrew, Russia and the cholera, 1823-1832, Madison and Milwaukee, University of Wisconsin Press, 1965; R J Morris, Cholera 1832: the social response to an epidemic, London, Croom Helm, 1976; M Durey, The return of the plague:
British society and the cholera, 1831-32, Dublin, Gill and Macmillan, 1979; M Pelling, Cholera, fever and English medicine, 1825-1865, Oxford University Press, 1978; F Delaporte, Disease and civilization: the cholera in Paris, 1832, Cambridge, MIT Press, 1986; R J Evans, Death in Hamburg: society and politics in the cholera years 1830-1910, Oxford University Press, 1987; A Hardy, 'Cholera, quarantine and the English preventive system, 1850-1895', Med. Hist., 1993, 37: 250-69. For North America see, C E Rosenberg, The cholera years: the United States in 1832, 1849, and 1866, University of Chicago Press, 1962; G Bilson, A darkened house: cholera in nineteenth-century Canada, University of Toronto Press, 1980.

${ }^{4}$ D Arnold, Colonizing the body: state medicine and epidemic disease in nineteenth-century India, Berkeley, University of California Press, 1993; M Harrison, Public health in British India: AngloIndian preventive medicine, 1859-1914, Cambridge University Press, 1994. 
initially in collaboration with Timothy Richards Lewis (1841-1886), a Welsh army surgeon, and later alone, Cunningham published extensively on many aspects of cholera. The corpus of work which he produced over nearly thirty years stands as the single most important late-nineteenth-century Anglo-Indian contribution to the search for the cause of the disease.

Despite Cunningham's considerable output and influence, he features only marginally in recent writing on cholera in colonial India. Harrison has briefly considered some of Cunningham's work as an example of Anglo-Indian scientific endeavour in the aftermath of Koch's visit to India. ${ }^{5} \mathrm{O} \mathrm{P}$ Jaggi quotes Cunningham merely as part of his rather dismissive discussion of the general reaction of IMS officers to Koch's discovery. ${ }^{6}$ Arnold mentions Cunningham only in passing as he pursues his thesis about the role of disease in the colonial enterprise. ${ }^{7}$

In failing to give Cunningham a central position in the cholera story, these writers have reinforced a negative historiographical approach to Cunningham which began in the early twentieth century. Cunningham was an implacable opponent of Koch, continually rejecting his bacillus as the true cause of cholera; when the latter's views on the cholera bacillus were vindicated at the turn of the century, Cunningham's work sank almost without trace. Cunningham's conflict with Kochian bacteriology can be understood only when the Indian cholera story is re-told with his full role intact.

Furthermore, Cunningham's science has a significance not fully appreciated by previous writers. I am particularly interested here in what Cunningham did in his laboratory. The role of the laboratory in "revolutionising" late-nineteenth-century medicine has been discussed by Andrew Cunningham, who takes the laboratory out of any political or social context and considers it merely as the place where germ theorists set to work reconstructing diseases. ${ }^{8}$ By this definition a laboratory is "made" by virtue of the scientific doctrine of those who work in it. Thus Cunningham describes Koch as a laboratory scientist and those who opposed him as practising some other, older, prelaboratory science. This implies that, in the context of epidemic disease, laboratory medicine was synonymous with Kochian bacteriology and that the laboratory was the exclusive preserve of Kochian bacteriologists. But D D Cunningham was also a laboratory scientist; in fact, he and Lewis were the first Anglo-Indian physicians to be specifically trained in fungal microscopy and culture technique. He, like Koch, worked in a room with chemicals, experimental animals and, of course, his microscope. We should therefore be cautious in proclaiming the "laboratory revolution in medicine", because this approach tends to obscure those laboratory scientists who were not revolutionaries. And we must be clearer about why some laboratory scientists were more successful than others; why it was that bacteriologists went on to construct the history of infectious disease in a way that so effectively excluded workers such as D D Cunningham.

5 Harrison, op. cit., note 4 above, pp. 110 , 113-15.

${ }^{6} \mathrm{O} P$ Jaggi, Western medicine in India: epidemics and other tropical diseases, Delhi, Atma Ram \& Sons, 1979, pp. 44-6, 61-2.

7 Arnold, op. cit., note 4 above, p. 194.
8 A Cunningham, 'Transforming plague: the laboratory and the identity of infectious disease', in A Cunningham and P Williams (eds), The laboratory revolution in medicine, Cambridge University Press, 1992, pp. 209-44. 


\section{D Cunningham and the Aetiology of Cholera}

In this paper I ask why, despite his use of the laboratory, D D Cunningham failed to reconcile himself to Kochian germ theory and was ultimately dispatched to anonymity. I argue that three factors combined to drive his work in an anti-Kochian direction. First, his cholera research was either initiated on political grounds or came under the control of officials with an explicit anti-contagionist political agenda. Second, Cunningham's predisposition towards a broad-based naturalism and his loyalty to the German hygienist Max von Pettenkofer, a popular influence in India and from the early 1880 s a fierce rival of Koch, precluded an easy conversion to Kochian bacteriology. Third, Cunningham sought to maintain a distinct Anglo-Indian medical tradition in opposition to Koch's universalizing "new" bacteriology.

That Cunningham was able to combine these influences in a viable research programme demonstrates that the view of the late-nineteenth-century laboratory simply as a conduit of scientific revolution is too narrow. The Indian cholera laboratory sustained Cunningham through nearly thirty years of research that was, at least in its later stages, thoroughly reactionary. He failed to take advantage of the bacteriological revolution, not because he was doing his research in the wrong scientific place, but because his scientific method and interpretation were determined by factors internal and external to his laboratory.

\section{Sanitary Policy in India}

The British presence in India had been threatened from its outset by epidemic disease. Throughout the nineteenth century, disease carried off more troops than all indigenous insurrections combined. ${ }^{9}$ However, after the 1857 mutiny, the colonial regime became acutely concerned with the need to maintain a healthy fighting force. It thus sought to record accurately the prevalence of illness in the army, and to develop effective preventive measures to control epidemic diseases such as cholera, which at that time was the single largest killer of British troops. ${ }^{10}$

This policy was institutionalized in the appointment to the Indian government of a Sanitary Commissioner to advise on the direction and implementation of public health policy. From 1866 to 1884 this position was held by Edinburgh graduate James McNabb Cuningham (1829-1905). J M Cuningham espoused a localistic approach to the aetiology of cholera in which the particular environmental characteristics of a locality had an intimate role in the generation of the disease. This doctrine had been popular among the medical profession in India since the early nineteenth century, but it was reinforced from the 1860s by the work of the German hygienist Max von Pettenkofer (1818-1901).

According to Pettenkofer's soil theory, the presence of the "specific germ" and a susceptible victim could not alone produce the disease. Only in the presence of the right soil conditions would the germ acquire its pathogenic properties and a cholera epidemic occur. By the late 1860 s Pettenkofer had developed his soil theory to a sophisticated level. In a celebrated equation the cholera germ was represented as $x$, the necessary soil

${ }^{9} \mathrm{R}$ Ramasubban, 'Imperial health in British India, 1857-1900', in R Macleod and M Lewis (eds), Disease, medicine and empire, London, Routledge, 1988 , pp. $38-60$, on p. 39.
${ }^{10} \mathrm{~S}$ Guha, 'Nutrition, sanitation, hygiene and the likelihood of death: the British army in India c.1870-1920', Popul. Stud., 1993, 47: 385-401, p. 394. 
conditions as $y$, and the poisonous combination as $z$. Thus, when $x+y=z$, cholera would arise from the earth and strike. ${ }^{11}$ Pettenkofer's denials of the sufficiency of the cholera germ in causing the disease culminated in his "experimentum crucis" of 1892, in which, having first neutralized his stomach, he swallowed a culture of cholera vibrios without apparent effect. ${ }^{12}$

As an anti-contagionist, Pettenkofer was opposed to the standard European response of imposing quarantines and cordons sanitaires. His approach appealed to the British, who, as keen maritime traders, stood to lose substantially if international trade were restricted. Anglo-Indians in particular were mindful of the adverse effects such measures would have on the economy of the Indian subcontinent and in particular Bengal, where cholera was endemic. By the 1880s quarantine regulations had been completely prohibited on the subcontinent, a policy justified by claims of their ineffectiveness. ${ }^{13}$ The sanitary authorities did not think it possible or desirable to restrict the movement of millions of people by preventing them fleeing from infected areas. Religious fairs attended by vast numbers were prime foci of cholera epidemics, yet the colonial regime was reluctant to interfere in the religious "freedom" of the indigenous population, particularly after the 1857 rebellion.

Instead, the government concentrated on surveillance of both the army and the indigenous population for outbreaks of epidemic disease. These records were presented annually in the Sanitary Commissioner's report. ${ }^{14}$ This document also served as an outlet for the views of the Commissioner, which, given that $\mathbf{J} \mathbf{M}$ Cuningham was an extreme localist, were often controversial. Expressing an absolute aversion to preventive measures based on contagionist thinking, J M Cuningham instead espoused a traditional sanitarian regimen of "pure air, pure water, pure soil, good and sufficient food, proper clothing, and suitable healthy employment for both mind and body". ${ }^{15}$ Sanitary policy was oriented towards improvement in general hygiene, in particular the removal of "filth" which J M Cuningham believed gave rise to pathogenic miasma.

The Indian Medical Service was largely supportive of $\mathbf{J}$ M Cuningham in his battle against quarantine and contagionism in general. J L Bryden (1833-1880), the first statistical officer in the colonial sanitary department, devoted many years of research to elaborating localist theories of the spread of cholera. ${ }^{16}$ Another firm supporter was Joseph Fayrer (1824-1907), a veteran of the Mutiny, who declared that "Experience in India has certainly taught us that in the ordinary sense of the term cholera is not contagious, and has demonstrated the futility of all quarantine measures." 17 However, opinion was not unanimous. "I cannot detect any circumstance in the behaviour of the disease", wrote a

11 E E Hume, Max von Pettenkofer, NewYork, Paul B Hoeber, 1927, pp. 45-8, 68-9. See also C E A Winslow, The conquest of epidemic disease: $a$ chapter in the history of ideas, Princeton University Press, 1943, pp. 311-36.

12 See Evans, op. cit., note 3 above, pp. 497-8, for an account.

13 J M Cuningham, Cholera: what can the state do to prevent it?, Calcutta, Supt. Govt. Printing, 1885, p. 24.

\footnotetext{
14 Annual report of the Sanitary Commissioner with the Government of India, Calcutta, Supt. Govt. Printing. Hereafter ARSCGI.

15 Cuningham, op. cit., note 13 above, p. 130.

16 An account of Bryden's work and reaction to it is provided by Harrison, op. cit., note 4 above, pp. 100-5.

17 J Fayrer, 'Opening address to the Medical

Society of London, 29th November 1883', in J Fayrer, Addresses and papers, Wellcome Institute RAMC Muniments Collection, vol. 1, pp. 73-80, on p. 79.
} 


\section{D Cunningham and the Aetiology of Cholera}

doctor from Alipore, "which militates against its being regarded as contagious." 18 A surgeon in Madras went against $\mathbf{J}$ M Cuningham in recommending that stools from cholera victims be buried three feet deep in a trench since "Cholera is propagated by the peculiar discharges from the bowels of Cholera patients". 19

Particularly vocal were the significant minority of Anglo-Indians who supported John Snow's water theory of cholera transmission. J M Cuningham was embroiled for much of his career in a dispute with Annesley Charles De Renzy, Sanitary Commissioner for the Punjab, who stood passionately by Snow's doctrine. The measures De Renzy wanted to employ to prevent cholera in the Punjab stood in diametric opposition to those of his superior. J M Cuningham solved this ideological battle by having De Renzy removed from his post and transferred to a remote military station. ${ }^{20}$

\section{8-9: Recruitment to the Cholera Enquiry}

In the late 1860 s pressure was mounting on the British to act to prevent cholera spreading from India to Europe. The International Sanitary Conference at Constantinople had demanded that the Indian government take further measures to control the disease on the subcontinent. ${ }^{21}$ The inadequacy of existing arrangements was starkly revealed in the 1867 epidemic, centred on the religious fair in Hardwar, in which over 100,000 people died. $^{22}$

Part of the British response to this situation was to initiate a scientific study of the aetiology of cholera to be carried out in India under the direction of $\mathbf{J} \mathbf{M}$ Cuningham. The idea for this project first surfaced at the army medical school at Netley, where Edmund Parkes (1819-1876) was Professor of Military Hygiene. Parkes and his professorial colleagues were particularly keen that the enquiry address the possibility of cholera being spread by some infectious matter in the stools of the victims. In a memorandum presented to the Netley Senate, Parkes declared that

It has been asserted by eminent botanists in Germany, that there are fungi of special character in the cholera discharges, and many physicians now believe that cholera spreads by the growth of these plants. The point is one of extreme interest, for if it be true, the prevention of cholera would probably be easy as the exact point to be aimed at would clearly be seen. If the statement be not true the sooner it is disproved the better. ${ }^{23}$

One of the botanists in question was Ernst Hallier (1831-1904), Assistant Professor in Jena. Hallier had proposed fungi to be the causative agent of numerous diseases, including cholera, typhoid, measles, syphilis and smallpox. He maintained that in cholera, ingested fungal spores would produce tiny organisms called micrococcus if allowed to remain in

18 R T Lyons, 'Cholera in Alipore', Indian Ann. med. Sci., 1873, 31: 117-39, p. 134.

$19 \mathrm{G}$ Bidie, 'The etiology of cholera, gleamed from the pages of its history, with practical remarks', Indian Ann. med. Sci., 1860, 13: 16-30, p. 28.

${ }^{20}$ A complete account of this controversy is given in J C Hume, 'Colonialism and sanitary medicine: the development of preventive health policy in the Punjab, 1860-1900', Mod. Asian Stud., 1986, 20: 703-24.
21 N Howard-Jones, The scientific background of the International Sanitary Conferences, 1851-1938, Geneva, WHO, 1975, p. 34.

22 D Arnold, 'Cholera and colonialism in British India', Past and Present, 1986, 113: 118-51, p. 139.

${ }^{23}$ Meeting of Senate, 6 June 1868, para. 6. Wellcome Institute RAMC Muniments Collection Temp 4/7/1-12 Senate Meetings of Army Medical School. Hereafter RAMC. 
the intestine for long enough. These particles would ultimately develop into mature fungi, which Hallier claimed to have found in the stools of cholera victims. The micrococcus, which Hallier classified as belonging to the "bacteria", was responsible for producing the disease. $^{24}$

Clearly, Parkes was impressed by the implications of a pathogenic organism being isolated and demonstrated to have an important role in the genesis of the disease. But it was clear to the professors that no one currently in India possessed the necessary skills to perform a study involving specialized microscopic and botanical research. They proposed, therefore, that the two most able doctors in the summer 1868 entry cohort for the Indian Medical Service and the Army Medical Department should be specially trained to undertake the enquiry. Entry to the IMS and AMD was by means of a competitive exam sat in London. The successful candidates then undertook a four month course in military medicine at Netley which culminated in a final examination. The marks from the entry exam in London and the passing-out exam at Netley were combined to give a single overall figure.

The highest scoring candidate in the IMS cohort was David Douglas Cunningham. Born in 1843, Cunningham was from Prestonpans, east of Edinburgh. His father was a clergyman, a common paternal occupation among IMS recruits, and his maternal grandfather was Lord Reston, Sheriff of Perthshire. After obtaining his medical degree from Edinburgh in 1867, Cunningham passed the London exam in April 1868 and was sent to Netley for the summer session. He was joined by Timothy Richards Lewis, a Welsh doctor, two years his senior, who obtained the highest mark in the AMD exam. Lewis, originally from Llanboidy, had trained as a chemist in London before studying medicine in Aberdeen.

After completing the formalities of entry to their respective services, Cunningham and Lewis were immediately placed on special duty for the duration of their work in India. Before they departed for the subcontinent, Parkes was determined that Cunningham and Lewis should be equipped with the special botanical skills necessary to pursue their investigation. He arranged for the two researchers to visit Germany in October 1868 to receive instruction from Hallier in Jena and from Anton de Bary (1831-1888), newly established as Professor of Botany in Halle. De Bary had taken a dim view of Hallier's experiments. He claimed never to have seen the micrococcus emanate from fungal spores and he dismissed Hallier's claims to have isolated and cultured fungi from cholera stools on the basis that Hallier's culture method was prone to contamination; writing to Parkes he described his disagreement with Hallier as "the question of Cholera fungus and Cholera-not-fungus". 25

Parkes refrained from proffering his own view of this debate in his Manual of practical hygiene, but it is clear that on the subject of transmission he was of a more open mind than the Sanitary Commissioner. Although impressed by "the very singular way in which cholera is sometimes localised", Parkes also declared that "The occasional, perhaps frequent, introduction [of cholera] by water seems certain. It is a good plan always to

\footnotetext{
24 See W Bulloch, The history of bacteriology, Oxford University Press, 1938, pp. 188-92, for a thorough description of Hallier's work.
}

\footnotetext{
25 Meeting of Senate, 25 July 1868, para. 5. RAMC.
} 


\section{D Cunningham and the Aetiology of Cholera}

change the source of supply when practicable."26 Parkes' liberal approach to the various theories of transmission extended to his treatment of Pettenkofer. He devoted a footnote in the Manual to a discussion of Pettenkofer's soil theory, but concluded that "the soil cannot be considered an essential factor [in the spread of cholera] though in some cases it is a very important one."27 Parkes was also at variance with Pettenkofer on the need for deep burial of cholera stools, a practice to which Pettenkofer was particularly averse.

Given Parkes' rather lukewarm opinion of Pettenkofer, it is highly significant that his two young researchers were persuaded by de Bary to extend their sojourn in Germany by paying a visit to Munich to see Pettenkofer himself. Cunningham and Lewis, having spent most of October 1868 with de Bary and Hallier, informed the Netley Senate of their diversion to visit "one of the first authorities in Germany on the subject of cholera". 28

Cunningham and Lewis spent only a matter of days with Pettenkofer as they were required to return to Britain to report back to Parkes before sailing to India on 12 December. However, in that short time they were exposed to, and successfully inculcated into, Pettenkofer's credo. When their reports of discussions with the German professors were serialized in the Lancet over three weeks in January 1869, it was Pettenkofer's views that appeared first. ${ }^{29}$ Lewis, in particular, retained a life-long friendship with Pettenkofer, whose views were to dominate most of his and Cunningham's cholera research. Indeed, Pettenkofer appeared optimistic about the enquiry's prospects now that Cunningham and Lewis had been apprised of his theories. "This undertaking", he told Parkes, "reflects honor on England in the estimation of the whole human race."30

Pettenkofer's influence was reinforced when J M Cuningham took over responsibility for the two researchers when they arrived in Calcutta in January 1869. Cunningham and Lewis had been given instructions "placing their services at the disposal of the Authorities", and the Sanitary Commissioner was eager to set them to work. ${ }^{31}$ Announcing the establishment of this study in the Sanitary Report for 1869 , J M Cuningham proudly declared that "The microscopic investigation of the disease in India affords a field which is of almost boundless extent, and which as yet has hardly been entered upon. The careful enquiries of such painstaking and able observers cannot fail to add much to our knowledge."32

Broader Anglo-Indian opinion also seemed pleased with the arrival of Cunningham and Lewis. The editors of the Indian Medical Gazette offered "our youthful confrères a hearty welcome to India, and bid them God speed with their glorious undertaking". ${ }^{33}$ But they were unequivocal in their insistence that Cunningham and Lewis should familiarize themselves with existing local knowledge relating to cholera. Without this, their newly

26 E A Parkes, A manual of practical hygiene: prepared especially for use in the medical service of the Army, 3rd ed., London, John Churchill, 1869, p. 481.

27 Ibid., p. 482.

${ }^{28}$ Meeting of Senate, 31 October 1868, para. 6. RAMC.

29 D D Cunningham and T Lewis, 'Scientific investigation into the causes of cholera. I. A report of interviews with Prof. Max Von Pettenkofer at Munich, Nov. 1868', Lancet, 1869, i: 3-4; idem, 'Scientific investigation into the causes of cholera.
II. Report of interviews with Professor de Bary, at Halle', Lancet, 1869, i: 38-41; idem, 'Scientific Investigation into the causes of cholera. III. Report of interviews with Professor Ernst Hallier, at Jena', Lancet, 1869, i: 76-8.

${ }^{30}$ Indian Medical Gazette, 1869, 4: 57. Hereafter IMG.

${ }^{31}$ Meeting of Senate, 25 July 1868, para. 5. RAMC.

32 6th ARSCGI (for 1869), published 1870, p. 72.

33 IMG, 1869, 4: 57. 


\section{Jeremy D Isaacs}

learned skills, acquired in Europe, might founder against the Indian terrain. "We would urge them", the editors enjoined, "to examine well what has already been done in the investigation of cholera in this country. They will find a mine of wealth in this direction, which will yield rich results if thoroughly explored." 34

The Netley professors had instructed Cunningham and Lewis "to allow no bias or prepossession to influence you, but to remember that you ... must enter on your enquiry in India without preconceived opinions." ${ }^{35}$ However, the three components which were to colour their work from its outset were now in place: Pettenkofer's environmentalist doctrine, J M Cuningham's localist agenda, and the expectation of the Anglo-Indian medical community that the newcomers' research would reflect the idiosyncrasies of their new home.

\section{The 1870s: D D Cunningham's Early Work}

Cunningham and Lewis spent their first six months in India acclimatizing. Part of the process of acquainting themselves with the terrain involved research into areas of interest not related to the cholera enquiry. Cunningham wrote a paper describing experiments "on the influence of snake-poison on the blood of animals". ${ }^{36} \mathrm{He}$ also attempted to ingratiate himself with Anglo-Indian opinion by reading a paper on the relation of fungi to disease at a meeting of the Bengal branch of the British Medical Association. ${ }^{37}$

Lewis was the first of the two researchers to publish work on cholera. In A report on the microscopic objects found in cholera evacuations Lewis tried, unsuccessfully, to reproduce the work of those German scientists whose claims had prompted Parkes to suggest his and Cunningham's mission. ${ }^{38}$ Lewis concluded that the cholera germ which Hallier "unhesitatingly affirms to be a fungus" could not, if it existed at all, be regarded as a "special" feature of cholera stools. He expressed his preference for Pettenkofer's putative germ, upon whose phylogeny the Munich professor had not been prepared to speculate. However, despite analysing soil in several military stations, Lewis was not prepared to draw any firm conclusions with regard to Pettenkofer's theory of causation.

This non-committal approach incurred the wrath of Kenneth McLeod, editor of the Indian Medical Gazette. "These observations and experiments [on soil]", he declared, "are most imperfect and inconclusive, even if the latter are not subject to most serious sources of fallacy, which we observe they are." 39 He was similarly unimpressed with Cunningham's first foray into cholera research, revealingly titled 'A report on choleraPettenkofer's theory illustrated in Madras' ${ }^{40}$ "The whole thing is as vague and indefinite as ever", McLeod complained.

\footnotetext{
34 Ibid.

35 Meeting of Senate, 26 September 1868, para. 7. RAMC.

36 D D Cunningham, 'Experiments on the influence of snake-poison on the blood of animals', IMG, 1869, 4: 249-50.

37 This paper also appeared as D D Cunningham, 'On the relation of fungi to disease', IMG, 1870, 5: $97-100$.

$38 \mathrm{~T}$ R Lewis, A report on the microscopic objects
}

found in cholera evacuations, \&c, Calcutta, Supt. Govt. Printing, 1870. This report also appeared as an appendix to the 6 th ARSCGI.

39 Review of T R Lewis, Investigations into the mode of origin and spread of cholera, and D D Cunningham, $A$ report on cholera, IMG, 1872, 7: 22-3, 46-7, p. 22.

40 7th ARSCGI (for1870), published 1871, appendix B, Dr D Cunningham's 'Report on cholera, part I-Pettenkofer's theory illustrated in Madras'. 


\section{D Cunningham and the Aetiology of Cholera}

It is easy enough to explain outbreaks of cholera by means of this elastic theory, which has as many loopholes as there are possibilities of the occurrence of cholera; but it was surely not to do what Pettenkofer can do in Germany that Dr. Cunningham was sent to India . . . We do most earnestly hope that this is the last specimen we shall see of this kind of cholera enquiry. ${ }^{41}$

Despite these criticisms, Cunningham and Lewis's position in India was secure for two reasons. First, although their soil analyses were derided, their microscopic work was acknowledged as the best which had yet been done in India. ${ }^{42}$ Their technical superiority thus ensured that Anglo-Indians remained convinced of their competence. Secondly, their work was carried out under the aegis of J M Cuningham. Indeed, the two papers discussed above appeared as supplements to the Sanitary Commissioner's Annual report. As long as J M Cuningham was satisfied with their work, Cunningham and Lewis enjoyed the continuing support of the authorities.

Laboratory experimentation was more in evidence in Cunningham and Lewis's collaborative reports of Microscopical and physiological researches into the nature of the agent or agents producing cholera published in 1872 and $1874 .{ }^{43}$ As part of their experiments they injected "choleraic and other organic fluids" into the veins of pariah dogs. Roughly half the creatures thus injected died with cholera-like symptoms. Seeking to avoid speculation as to a possible bacterial involvement in this process, the researchers injected another series of dogs with choleraic material which had been boiled for several minutes. This action did not diminish the mortality rate among the injected animals. However, the minds of the researchers must have been puzzled by some aspect of their work, for they wrote of choleraic fluids that

Something ... is present which ... is capable of exercising a singularly pernicious effect on animal life, the most prominent local manifestation of its action being observed in the intestinal canal. What is this something? Is it visible? Is it a living substance? With regard to the first of these questions we would not presume to speak decisively, although we ourselves have searched for it in vain with lenses which have the reputation of being the very best hitherto constructed and have been uniformly unsuccessful in associating it with any visible phenomena. ${ }^{44}$

Their microscopic work failing to yield significant results, Cunningham and Lewis took to the field for their last collaborative effort, Cholera in relation to certain physical phenomena, published in $1878 .{ }^{45}$ This lengthy document, consisting largely of analyses of epidemiological and meteorological data taken from military and civil stations throughout India, marked the high point of Anglo-Indian environmentalist thinking with respect to the aetiology of cholera. The authors prefaced their work by stating that the link between

41 Op. cit., note 39 above, p. 22.

42 Of Cunningham and Lewis's first microscopic work, the $I M G$ editors declared, "We have no hesitation in saying that we have never had so complete a description of the microscopic appearances of the discharges of cholera, and that the descriptions are more valuable for their care and minuteness, and the representations more numerous and artistic, than anything we have ever read or seen on this subject." IMG, 1872, 7: 46.

43 T R Lewis and D D Cunningham, $A$ report of microscopical and physiological researches into the nature of the agent or agents producing cholera,
Calcutta, Supt. Govt. Printing, 1872; idem, A report of microscopical and physiological researches into the nature of the agent or agents causing cholera: $a$ second series, Calcutta, Supt. Govt. Printing, 1874.

44 Idem, A report of microscopical and physiological researches, 1874 , op. cit., note 43 above, p. 56.

45 Idem, Cholera in relation to certain physical phenomena: a contribution towards the special enquiry sanctioned by the Right Hon. the Secretaries of State, for War, and for India, Calcutta, Supt. Govt. Printing, 1878. 
cholera prevalence and physical conditions was "generally admitted by the adherents of all theories regarding the essential cause of the disease". 46 A vast range of physical factors was investigated, including atmospheric pressure, temperature, humidity, rainfall and level of soil water. In their discussion, Cunningham and Lewis rehearsed their usual intention of not wishing to use their results to prejudice debate in favour of one theory or another. However, their claims of impartiality were somewhat transparent since the introduction to the study consisted of a seven page resumé of Pettenkofer's soil theory, described as a "brief summary of our conception of the learned Professor's views". 47

In reaching their conclusions, Cunningham and Lewis drew a parallel with malaria, a disease whose connection with soil "as a connection implying cause and effect, is not seriously questioned". ${ }^{48}$ They accepted that not all phenomena relating to the distribution of cholera could be explained by coincident conditions of the soil, but stressed that cholera had

as good a claim as malarial diseases to a telluric origin. What the essential cause may be remains unknown in both cases; but the fact that the production of malaria is so greatly under the control of improvements in local conditions warrants us in looking confidently to similar results with regard to the cause of cholera also. ${ }^{49}$

This conclusion reflects a pattern visible in Cunningham and Lewis's work. Although only tentatively addressing the issue of the cause of cholera, they still endorsed a localistic response to disease control. The immediate audience for their work was an Anglo-Indian community divided over the causes and control of epidemic disease. An appearance of impartiality was therefore required of the special assistants of the Sanitary Commissioner, as though their scientific investigations were carried out above the heat of the debate. In avoiding a firm endorsement or rejection of any particular aetiological theory, Cunningham and Lewis were in fact masking a highly contentious and ideologically driven sanitary policy.

Although recruited by Parkes, Cunningham and Lewis worked in India under the direction of $\mathbf{J} \mathbf{M}$ Cuningham. Consequently, their research programme represented no more than an elaborate attempt to validate British sanitary policy in India. J M Cuningham himself wrote that "The policy of the Government of India is to reject all theories as a basis of practical sanitary work." 50 As far as their mentor in the Sanitary Commission was concerned, the object of Cunningham and Lewis's exercise had never been to prove one theory over another, nor was it an attempt to contribute more widely to international debate. The investigations served a function in India alone, namely the legitimation of a sanitary policy which emphasized the importance of local environmental conditions, especially in barracks, prisons, military stations and other localities where the colonial presence was threatened by disease.

\section{The 1870s: The Broader Picture}

Three further points stand out from this early period. First, Cunningham and Lewis were conducting two semi-autonomous lines of enquiry. Their laboratory-based research was pursued at different times and published in separate reports from their environmental

\footnotetext{
46 Ibid., p. 1.

47 Ibid., p. 5.

48 Ibid., p. 112.
}

49 Ibid., p. 115.

50 Cuningham, op. cit., note 13 above, p. vi. 


\section{D Cunningham and the Aetiology of Cholera}

field work. Their laboratory was the space in which they tested the theories of Hallier and de Bary; the locality was the terrain in which Pettenkofer's soil theory was explored. One consequence of this was that the programme set for Cunningham and Lewis by the Sanitary Commissioner encompassed an enormous range of disciplines. Although modern boundaries between areas of research had not yet been formulated, the breadth of the investigations required of the two men was considerable even by Victorian standards. Their work in this period contained elements of microscopy, gross anatomy, epidemiology, soil science, bacteriology and geology. This is significant in that it depicts an approach to scientific study which strongly resisted the increasing specialization of the late nineteenth century.

Second, it is clear that the experimental part of what Cunningham and Lewis were doing was laboratory science. They were sent to India by Parkes to look for Hallier's cholera-fungus, and many of their experiments were designed to reproduce the effects of this putative germ in animals. This involved all the tools and techniques of the laboratory. To perform research of this nature one needed to be conversant with the emerging doctrine of germ theory. And Cunningham was by no means an opponent of germ theory per se. His work from the 1870 s, in particular Microscopic examinations of air revealed a sensitive appreciation of the workings of Pasteurian germ theory. ${ }^{51}$

Microscopic examinations of air described a series of experiments in which Cunningham exposed glycerine-coated microscope slides to the air for periods of twentyfour hours. The slides were contained in a device called an "aeroconiscope" which was designed to keep the slide facing the oncoming wind. ${ }^{52}$ Cunningham examined the daily "catch" of organisms, and attempted to correlate this with the incidence of ague, dysentery, diarrhoea, dengue and cholera in the adjacent Presidency jail. He was unable to confirm any relationship between the number and type of organisms in the air and the incidence of disease, but he did demonstrate some incidental findings such as the increased numbers of fungal spores present after rain. ${ }^{53}$ The pamphlet was enthusiastically reviewed in the British scientific press. In reproducing the conclusions of Microscopic examinations of air, the editors of Nature declared that "A work of the greatest importance ... has just been published in Calcutta by Mr. Douglas Cunningham. The conclusions which he has reached as a result of the experiment are so valuable that we deem it right to give them as great publicity as possible." 54 Indeed, Microscopic examinations of air proved to be Cunningham's most enduring work, earning him a place in Bulloch's History of bacteriology for countering F-A Pouchet's assertion that the earliest stages of the fungal life-cycle were never found free-floating in the air. ${ }^{55}$

\footnotetext{
51 D D Cunningham, Microscopic examinations of air, Calcutta, Supt. Govt. Printing, 1874.

52 This was a modified version of an instrument designed by a Dr R L Maddox, and illustrated in R L Maddox, 'On an apparatus for collecting atmospheric particles', Mon. microscop. J., 1870, 3: $286-90$.

53 A concise account of Microscopic examinations of air and the mycological background to this work can be found in G C Ainsworth, Introduction to the history of mycology, Cambridge University Press, 1976, p. 200.
}

\author{
${ }^{54}$ Nature, 1874, 9: 330. \\ 55 Bulloch, op. cit., note 24 above, p. 103.
} Bulloch describes Microscopic examinations of air as an "exhaustive monograph". Ainsworth, op. cit., note 53 above, is also complimentary, proclaiming the pamphlet to be "One of the first and most comprehensive attempts to correlate the incidence of disease in man with variations in the airspora" (p. 200), and noting the "pioneering work of D D Cunningham" in the field of Indian fungi (p. 230). 


\section{Jeremy D Isaacs}

So, to a limited extent, Cunningham did participate in a wider aetiological debate during the 1870s. His lengthy analysis of Pettenkofer's theory in Madras was praised in Pettenkofer's journal Zeitschrift für Biologie for "providing a criticism of the extensively held belief of English doctors that there is a direct link between the contagion [of cholera] and the transmission of germs in drinking water."56 Wishing to disseminate Pettenkofer's thinking among the Anglo-Indian medical community, Cunningham published his own translations of Pettenkofer's key papers on cholera and typhoid aetiology. ${ }^{57}$ For Pettenkofer, having a follower of his own doctrine working in India must have been appealing, for he himself never set foot in that country, despite publishing widely on the prevalence of cholera in different regions of the Indian subcontinent.

Finally, while pursuing his government-directed studies, Cunningham also published widely on botanical issues. His detailed and extensive work on plant life appeared in such journals as the Proceedings of the Royal Society, and the Transactions of the Linnean Society. ${ }^{58}$ In 1880, Cunningham's botanical skills were called upon when he acted temporarily as superintendent of the Calcutta Royal Botanic Garden. Cunningham's botanical work and his general disposition towards a broad-based naturalism informed his entire scientific approach, and affected his method and interpretation with respect to cholera research.

Cunningham and Lewis worked on other joint projects of concern to the sanitary authorities throughout the 1870s. The "Oriental sore", the "fungus-disease", and leprosy all came under their gaze. ${ }^{59}$ Cunningham was rewarded for his efforts by being appointed Professor of Physiology at the Calcutta Medical College in 1879 . He continued to take an interest in cholera, but his published work of the early 1880 s reflected a broader range of topics, from the strictly botanical to the directly pathological. ${ }^{60}$

Lewis, meanwhile, left India for good in 1883 to take up the post of Assistant Professor of Pathology at Netley. At this point the "special cholera enquiry" was officially terminated, leaving Cunningham to pursue his academic interests in Calcutta. ${ }^{61}$ However, he was soon recalled by the state for active scientific service when, in February 1884, Robert Koch announced that he had isolated the causative agent of cholera in India.

\footnotetext{
56 'Dr. Douglas Cunningham's Untersuchungen über Pettenköfer's Theorie auf Madras angewendet', Zeitscrift für Biologie, 1872, 8: 267-93, p. 267. I am grateful to Mark Thristan for translating this paper.

${ }^{57}$ M Pettenkofer, 'Typhoid fever: its relation to soil water', transl. D D Cunningham, Indian Ann. med. Sci., 1873, 31: 79-95, and idem, 'Cholera in ships and the aim of quarantines', transl. D D Cunningham, Indian Ann. med. Sci., 1873, 31: 189-257.

58 For example, D D Cunningham, 'On the occurrence of conidial fructification in the Mucorini, illustrated by Choanephora', Linn. Soc. Tran. (Bot), 1880, 1: 409-22, and D D Cunningham, 'On the relation of particular structural features in certain leaves to the phenomena of nyctitroprism and movements incident on stimulation by concussion', Roy. Soc. Proc., 1883, 34: 268-72.
}

59 T R Lewis and D D Cunningham, The oriental sore, as observed in India: a report, Calcutta, Supt. Govt. Printing, 1877; idem, The fungus-disease of India: a report of observations, Calcutta, Supt. Govt. Printing, 1875; idem, Leprosy in India: a report, Calcutta, Supt. Govt. Printing, 1877.

${ }^{60}$ Examples from this period include D D Cunningham, 'On Mycoidea parasitica, a new genus of parasitic algae, and the part which it plays in the formation of certain lichens', Linn. Soc. Trans. (Bot), 1880, 1: 301-16; idem, 'On certain effects of starvation on vegetable and animal tissues', $Q . J$. Microsc. Sci., 1880, 20: 50-78; idem, 'On the development of certain microscopical organisms occurring in the intestinal canal', Q. J. Microsc. Sci., 1881, 21: 234-90.

61 19th ARSCGI (for 1882), published 1883, p. 161 . 


\section{D Cunningham and the Aetiology of Cholera}

\section{The 1884-7: Responding to Koch}

The events surrounding Koch's visit to Calcutta and his identification of the cholera bacillus have been documented by Thomas Brock and others. ${ }^{62}$ Less thoroughly examined by historians has been the response of the British scientific and political establishment to the challenge posed by Koch's work. In order to contest Koch's findings, Anglo-Indian science had to enter the cholera debate at an international level, and address Koch on his own terms.

The first response of the British government was to appoint its own cholera commission, consisting of two London pathologists, Heneage Gibbs and Emanuel Klein. During November 1884 the commission worked in the same laboratory in Calcutta as had been used by Koch. Cunningham broke off from his duties at the Calcutta Medical College to escort Klein to the water tank from which Koch had isolated the comma bacillus. There had been cases of cholera among regular users of the tank and Koch had claimed that the bacilli which he had obtained from the stools of victims of the disease, both in India and in Egypt, were identical to the bacteria in the tank. Klein also took water from this tank and from it cultivated bacteria which "were identical in every respect with those found in choleraic dejecta." ${ }^{63}$ However, Klein remained sceptical of the role of these bacilli in causing the disease.

Notwithstanding their presence in this water, and notwithstanding the extensive use the two hundred families were constantly making of it, there has been no outbreak of cholera ... [This is] clearly because the water did not contain the active cholera virus, and because this latter cannot be identical with the comma-bacilli. ${ }^{64}$

This repudiation of Koch rested on an argument that Klein and Cunningham were both to repeat during their careers: that Koch had not proved that the proliferation of comma bacilli in the intestines of victims was anything more than a consequence of the disease. Indeed, Koch had been unable to reproduce cholera in an animal model by direct ingestion or inoculation of the comma bacillus. Lewis, safely ensconced in England, also attacked Koch for producing "no evidence to show that [comma bacilli] are more pernicious than any other microbe". 65

However, the colonial sanitary establishment had been considerably embarrassed by Koch's discovery and resolved to persist in disputing his claims. If Koch's comma bacillus genuinely were the cause of cholera then a mockery had been made of half a century of localist theory. The implication of a contagious organism being the enemy rather than a particular locality was that spread of the disease could be arrested only by strict quarantine measures. The editors of the Indian Medical Gazette feared that "still more stringent quarantine regulations" might be imposed on Indian ships by European governments taken in by the rewards being lavished on Koch by the German state. ${ }^{66}$ "Koch's fragmentary researches on cholera", they declared, "will have been the means of inflicting

62 T D Brock, Robert Koch: a life in medicine and bacteriology, Madison, Science Tech, 1988, pp. 140-68. See also W Coleman, 'Koch's comma bacillus: the first year', Bull. Hist. Med., 1987, 61: $315-42$.

${ }^{63}$ E Klein, The bacteria in Asiatic cholera,
London, Macmillan, 1889, p. 157.

64 Ibid.

65 'Memorandum on the "comma-shaped bacillus", alleged to be the cause of cholera', IMG, 1884, 19: $300-1$, p. 300.

66 'Current medical topics', ibid., p. 205. 
much grievous and . . . undeserved pecuniary loss upon Indian commerce." ${ }^{\circ 7}$ This outcome was something which the Indian government was anxious to avoid. Joseph Fayrer, at that time president of the India Office Medical Board, warned that

The evil results of the contagion theory have been manifested not only in the rigours and hardships of quarantine, whereby great suffering ... and incalculable damage to commercial interests have been effected, but in the general state of panic and demoralisation which has deranged and degraded society generally. ${ }^{68}$

The work of the English cholera commission highlighted the need for greater facilities to be at the disposal of those scientists whom the state appointed to defend its position. ${ }^{69}$ Thus, in December 1884, the Indian government gave the Sanitary Commissioner 15,000 rupees to establish a biological laboratory, with Cunningham as its director. This was constructed in the grounds of the Calcutta Presidency General Hospital, from which a steady supply of cholera cases would be available. There was palpable relief in the tone of the Indian Medical Gazette's editors when they announced that Cunningham, "whose name is so intimately associated with cholera research, will follow up and extend Dr. Koch's line of investigation."70

In the same year, Cunningham was also provided with a vehicle with which he could take the debate to Koch and formally argue his case. Scientific Memoirs by Medical Officers of the Army of India was the first Anglo-Indian journal devoted entirely to biological research. It was established by the new Sanitary Commissioner, Benjamin Simpson, who selected all the papers for publication. ${ }^{71}$ The journal had a clear political role: to act as the scientific arm of the annual sanitary reports and thus present scientific justifications of policy decisions.

The first issue of the journal, published in Calcutta in 1885, contained just two papers, both by Cunningham. In the first, 'On the relation of cholera to schizomycete organisms', Cunningham, like Klein, responded directly to Koch by taking samples from water tanks in Calcutta and searching in them for comma bacilli. ${ }^{72}$ When the contents of two samples were cultured, a development of comma bacilli occurred, but, curiously, the subject was

unfortunately not pursued further at that time ... due to the press of other work ... In the meantime the results as far as they go must be regarded as enforcing the necessity of caution in coming to hasty conclusions in regard to the interpretation to be put on the phenomenon of the presence of cultivable commas in sources of water supply. ${ }^{73}$

The object of the paper was, however, more specific than a mild warning about focusing too narrowly on water supply as the source of cholera. In his culture experiments Cunningham became convinced that far from one discrete type of bacterium being

67 Ibid.

$68 \mathrm{~J}$ Fayrer, 'A lecture addressed to the YMCA at Exeter Hall, 2nd March 1886', in op. cit., note 17 above, pp. 282-317, on p. 302.

69 20th ARSCGI (for 1883), published 1885, p. 162 .

70 'The cholera germ', IMG, 1884, 19: 232-4, p. 234.

71 21st ARSCGI (for 1884), published 1886, p. 160.
72 D D Cunningham, 'On the relation of cholera to schizomycete organisms', Sci. Mem., 1885, 1: 1-20.

73 Ibid., p. 11. The "other work" may have included research into "Delhi boil", which was published in the same year in D D Cunningham, On the presence of peculiar parasitic organisms in the tissue of a specimen of Delhi boil, Calcutta, Supt. Govt. Printing, 1885. 


\section{D Cunningham and the Aetiology of Cholera}

associated with cholera, the comma bacillus was capable of existing in a number of different morphological forms. Different types of culture would produce different types of comma bacillus. This theory of "polymorphism as a character of the choleraic commas under the influence of varying conditions" was controversial among both germ theorists and those more broadly interested in bacterial classification. In acknowledging this, Cunningham revealed his naturalist instincts.

I am well aware that the conclusions at which I have arrived, whilst in accordance with the views of many botanical workers, are in direct conflict with those of the majority of pathological bacteriologists, and that I am therefore laying myself open to much adverse criticism in publishing them. ${ }^{74}$

In his next contribution to the cholera debate Cunningham made no mention of his polymorphic theory. In the second issue of Scientific Memoirs, published in 1887, his work showed a clear shift onto Koch's agenda. 'On the effects sometimes following injections of choleraic comma-bacilli into the subcutaneous tissues in guinea-pigs' reads like a manual of practical germ theory. ${ }^{75}$ Cunningham obtained a sample of rice-water stools rich in comma bacilli from a cholera victim. An unfortunate guinea-pig had a solution containing this material injected into its left thigh and died three days later. A sample of comma bacilli cultured from the cardiac blood of this animal was injected into a second guinea-pig. This too died. A third animal injected with commas from the second survived, however. Another guinea-pig injected with the original bacteria also survived. Of the dead guinea-pigs, Cunningham wrote, "There can, I believe, be no reasonable doubt that the commas exerted a specific pathogenic influence in these cases." ${ }^{76}$ However, he refused to accept that this necessarily confirmed a causal link between the comma bacilli and cholera, and remained puzzled by the survival of two of the animals. Once again, rather than directly criticizing Koch, Cunningham used his ambiguous results to formulate a new and original theory. First, he concluded that the sites in the body in which pathogenic bacteria were found in abundance did not necessarily correspond with the site of invasion. With this in mind he suggested that the route taken by the bacteria following their injection into the guinea-pigs "was from the subcutaneous lymphatic spaces to the great peritoneal one and thence by direct penetration of the walls of the intestine tube to its cavity. All direct evidence of such a process of penetration is, however, wanting". 77 Although this conclusion was tentatively drawn, its implications were clear. If cholera could be induced by comma bacilli entering the body at any location, then there would be no need for sanitary policy to concentrate on water supply over and above any other potential source of bacteria. Yet again the political context of Cunningham's work was revealed in his conclusions.

Cunningham's strategy throughout the 1880 s was to downplay the role of the cholera vibrio in causing the disease without dismissing it outright. Such an approach was mirrored in the public statements of other prominent Anglo-Indians such as Joseph Fayrer,

\footnotetext{
74 Cunningham, op. cit., note 72 above, p. 11. Cunningham may have followed the work of the botanist Carl von Nägeli, who insisted on the nonspecificity of bacterial form. For a brief discussion of disputes over bacterial classification, see Coleman, op. cit., note 62 above, pp. 328-9.
}

\footnotetext{
75 D D Cunningham, 'On the effects sometimes following injection of choleraic comma-bacilli into the subcutaneous tissues in guinea-pigs', Sci. Mem., 1887, 2: 1-14.

76 Ibid., p. 10.

77 Ibid., p. 11.
} 
who declared in 1888 that "Whilst fully recognising the great value of these bacteriological researches and their bearing upon aetiology ... I demur to a microbe being accepted as the solution of such a problem as the cause of cholera."78

\section{8-89: Opening up the Laboratory}

Cunningham's work on cholera underwent a change in course in 1888, with the publication of a paper describing attempts to cultivate comma bacilli in earth, cow dung, and human excreta. ${ }^{79}$ The results indicated the "general feebleness" of the cholera vibrios, prompting Cunningham to "regard their agency in the production of epidemics as entirely subordinate to the influence of local conditions securing the presence of media ... favouring their continued development." 80 Here, for the first time since Koch's discovery, Cunningham emphasized the requirement that any proposed cause of cholera must explain the behaviour of the disease during an epidemic.

A similar approach was apparent in the title of Cunningham's 1889 paper, 'Are choleraic comma-bacilli, even granting that they are the proximate cause of choleraic symptoms, really efficient in determining the epidemic diffusion of cholera?'81 This paper was concerned with experiments on the behaviour of comma bacilli in water and in soil. Once again, however, Cunningham's conclusion was not drawn from his findings but was a statement of rhetoric.

... no contagionist theory will account for the phenomena of epidemic diffusion of the disease, and ... the only one which will do so must be of the nature of that which has been so long advocated by the observer who has done most to advance our knowledge of the subject. It is very possible to differ from Von Pettenkofer in regard to matters of detail, and yet to believe that he has all along been in the right in insisting on the primary importance of local conditions. ${ }^{82}$

The significance of this paper to Cunningham's scientific development extends beyond its more explicit support for Pettenkofer. The emphasis in the title on accounting for the epidemicity of cholera marks a shift away from the laboratory and into the field. However, this field work was of a different nature from that which Cunningham and Lewis had performed in the 1870s. Koch's discovery had exposed the redundancy of pursuing two semi-independent lines of enquiry. The answer to the cholera question would now be explained from the laboratory bench. Yet Cunningham demanded that the "epidemic diffusion" of cholera be explained. Kochian germ theory may have been able to link the comma bacillus with the disease in the controlled conditions of the laboratory, or even within the confines of a well regulated German city, but it could not account for the epidemicity of the disease in India. Hence, the truly Indian laboratory would engage with the environment and take the techniques of the bacteriological laboratory-microscopy and culture- to the land in a way that Koch had not.

$78 \mathrm{~J}$ Fayrer, 'The natural history and epidemiology of cholera. Annual oration of the Medical Society of London, 7th May 1888', in op. cit., note 17 above, pp. $318-64$, on p. 350 .

79 D D Cunningham, 'Notes from the biological laboratory attached to the Office of the Sanitary Commissioner with the Government of India', Sci. Mem., 1887, 3: 1-16.
80 Ibid., p. 16.

81 D D Cunningham, 'Are choleraic commabacilli, even granting that they are the proximate cause of choleraic symptoms, really efficient in determining the epidemic diffusion of cholera?', Sci. Mem., 1889, 4: 1-20.

82 Ibid., p. 19. 


\section{D Cunningham and the Aetiology of Cholera}

By attempting to bring the field into the laboratory, even to make India itself the laboratory, Cunningham was challenging Koch on two fronts. First, he was changing the frame of debate. When laboratory experiments confirmed the doctrine of only one side of the debate, the other side used epidemiological considerations as a way of shifting the battleground. ${ }^{83}$ By the 1890 s, for example, Cunningham was referring to Pettenkofer as an epidemiologist, reflecting the scientific discourse in which his theories had most explanatory power.

Second, Cunningham made use of the Indian terrain because he could claim an understanding of it not possessed by Koch. I shall shortly examine how Cunningham attacked Koch for his relative inexperience of the idiosyncratic Indian environment. By invoking the "special" nature of India, which they alone were able to comprehend, AngloIndians sought to resist the universalizing hand of European bacteriology. Indeed, while the strongest advocates of the bacillus remained in Europe or were Europeans merely visiting the subcontinent, Anglo-Indians could exempt their country from the rules which governed the bacillus thousands of miles and many cultures away.

But Cunningham's laboratory was no more a neutral territory than the country outside it. His laboratory had been set up by the colonial authorities expressly to counter Koch, and results were expected. In India and Europe the political implications of Koch's ideas made them unpalatable to scientists who might nevertheless have found them difficult to dispute in the laboratory. ${ }^{84} \mathrm{~A}$ greater truth was therefore required of Koch's comma bacillus. Its mere existence was not sufficient for its role in cholera to be accepted, it also had to "do the right thing" politically. This has been graphically illustrated by Richard Evans, who charts the gradual acceptance of Koch's bacillus in Germany, where the political ramifications of germ theory coincided with the priorities of the nascent Reich. ${ }^{85}$ In India, however, so long as the consequences of a bacterial aetiology were large-scale quarantine and disinfection, the role of the bacterium would be contested by scientists allied to the government.

Bringing all these elements together to form a viable research programme meant making a compromise. Cunningham was clearly expected to use his laboratory to defeat Koch, but could not do so on this terrain. So he opened the door and let the land in. Hence the emphasis on epidemicity, on the behaviour of the bacillus in the environment, on accounting for the characteristics of cholera as it pertained to India. Thus Cunningham was able to resist Koch's bacillus without conceding the laboratory bench.

${ }^{83}$ A similar shift can be seen in the debate between Lister and his opponents in Britain in this period. From initial conflict came compromise built by moving the focus of attention from specific germs (antisepsis) to a wider "science of cleanliness" (asepsis). Historiography may present the Listerians as the winners, but closer examination reveals a concession of territory to the losing side. In the same way, a historiography biased towards Koch conceals the limitations of his germ theory as they were exposed at the time. From this series of victories and concessions emerges a new, wider "science of epidemics", in which the agenda has been set by the losing side. For a discussion of this debate see L Granshaw, "'Upon this principle I have based a practice": the development and reception of antisepsis in Britain, 1867-1890', in J V Pickstone (ed), Medical innovations in historical perspective, Basingstoke, Macmillan, 1992, pp. 17-46, and C Lawrence and R Dixey, 'Practising on principle: Joseph Lister and the germ theories of disease', in C Lawrence (ed.), Medical theory, surgical practice: studies in the history of surgery, London, Routledge, 1992, pp. 153-215.

84 Evans, op. cit., note 3 above, p. 268.

85 Ibid., pp.-243, 268. 
When he was elected a Fellow of the Royal Society in June 1889, Cunningham had held the chair of physiology at the Calcutta Medical College for ten years. His academic reputation was at its height and his work had achieved a high profile in Britain and was frequently quoted by authors of cholera tracts opposed to Koch. ${ }^{86}$ To assume that Cunningham could simply have changed sides underestimates his profound commitment to Pettenkofer's doctrine as both a theory and a foundation for sanitary policy; it neglects Cunningham's attachment to the land and his immersion in Anglo-Indian medical tradition; and it ignores the reason for which Cunningham's laboratory had been established.

\section{The 1890s: New Species, Old Criticisms}

The Scientific Memoirs of 1891 contained a paper in which Cunningham claimed to have identified ten different species of cholera bacilli from cases of the disease occurring in hospitals in Calcutta. ${ }^{87}$ The various species were differentiated on the basis of morphology and behaviour when cultivated under different conditions. The first species (connoted by an alpha) corresponded to Koch's bacillus, the others were distinctly different. Cunningham suggested that germ theorists had failed to identify these different comma bacilli in the previous seven years because of their blind enthusiasm for Koch's bacillus and their haste to link it conclusively with the disease. He used his findings to undermine Koch's theory that only one type of bacterium could be responsible for cholera. Koch, he claimed, had arbitrarily selected one of the species associated with the disease "because it happened to be present in a limited number of cases which specially came under his observation." 88

But Cunningham did not rest here. He was convinced that each species of comma bacillus was the result of differing conditions in the locality in which the case of cholera occurred. The cases which he examined at the General Hospital were associated with one species, cases from the Medical College Hospital with another, and those from the Sealdah Hospital with a third. Cunningham maintained that no one species could be regarded as bearing "an exclusive and specific relation to the occurrence of the disease" ${ }^{89}$ Rather, several distinct species were involved, the particular type found depending on local conditions. This theory was not without political implications: "as the disease is associated-certainly in India, and probably in Europe also-with many different species, it would obviously be futile to attempt to prevent the diffusion of these from India until it had been certainly shown that none of them were native to Europe." 90 This conclusion fitted in very well with the position of the Indian government. In the face of continuing international pressure for the quarantining of Indian trading ships, the colonial regime was attempting to deny that all cholera epidemics necessarily originated on the subcontinent. ${ }^{91}$

\footnotetext{
${ }^{86}$ For example J Chapman, Cholera curable: $a$ demonstration of the causes, non-contagiousness, and successful treatment of the disease, London, J \& A Churchill, 1885, p. 53.

87 D D Cunningham, 'On some species of choleraic comma-bacilli occurring in Calcutta', Sci. Mem., 1891, 6: 1-50.
}

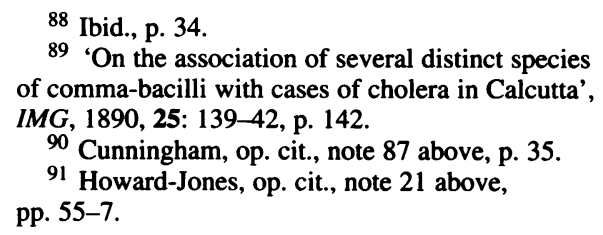

88 Ibid., p. 34.

89 'On the association of several distinct species of comma-bacilli with cases of cholera in Calcutta', G, 1890, 25: 139-42, p. 142 .

90 Cunningham, op. cit., note 87 above, p. 35 pp. 55-7. 


\section{D Cunningham and the Aetiology of Cholera}

Cunningham developed his aetiological argument in the 1894 edition of Scientific Memoirs. ${ }^{92}$ He now divided the clinical course into two discrete periods. The symptoms associated with the initial period of the disease, were, he claimed, due to the action of a specific but as yet unidentified poison, manufactured in the environment and ingested by the patient. This poison induced profound changes in the character of the intestinal canal, which in turn produced an alteration in the composition of the naturally occurring intestinal bacteria, including the various comma bacilli. When the population of a particular species of comma bacillus reached pathological proportions, these bacteria started producing toxic products which caused the symptoms associated with the second half of the disease. The outcome of the attack of cholera depended essentially on the capacity of the comma bacilli to produce these toxins.

In this paper Cunningham departed fundamentally from Pettenkofer for the first time. Pettenkofer had always maintained that the cholera poison, having left the intestine of a victim, could infect new hosts if the environmental conditions were right. For Cunningham, however, even this modest concession to contagionism was too much, and his reworking of Pettenkofer's localism involved

ceasing to regard the bodies of the sick, as in any sense specially related to the manufacture of the essential cause of the disease, as in any sense forming an essential site for the manufacture and multiplication of the specific poison which induces the characteristic phenomena of cholera. ${ }^{93}$

Quite how the poison was manufactured, and what it was, Cunningham did not say. This was not what the paper was about. Its essential feature was an attack on Koch, and on contagionism with respect to cholera in general. Right at the start of the paper Cunningham expressed his bitterness that his work had been rejected or made to fit in with the results of other researchers, when in fact they were contradictory. Then he turned on Koch, expressing ten years of frustration at the general acceptance of Koch's work.

Are we to assume that he was endowed with supernatural powers of diagnosis, which rendered him capable of infallibly discriminating true cases of cholera and avoiding errors to which Indian medical men with a lifelong experience of the disease are liable? It is all very well to regard Koch's work in connection with cholera as typical, but if it were typical of anything, it was of imperfect observation and rash generalisation. ${ }^{94}$ [My emphasis.]

This criticism recurred repeatedly in Cunningham's work. He constantly reproached Koch for having missed essential clues which the trained Anglo-Indian eye would have spotted with little difficulty. Cunningham's resentment of Koch extended to publicly belittling his status as a visiting scientist.

The theory which Koch has constructed on the basis of his discovery of the association of comma bacilli with cholera may be regarded as an excellent example of theories frequently founded by tourists in a new country on the basis of their original observations. His observation was perfectly correct, but the theoretical structure which he proceeded to raise upon it was utterly fallacious because it assumed that observations and experiments of a few weeks duration afforded sufficient ground for conclusions in regard to the details of phenomena presenting themselves under all circumstances. ${ }^{95}$ [My emphases.]

92 D D Cunningham, 'The results of continued study of various forms of comma-bacilli occurring in Calcutta', Sci. Mem., 1894, 8: 1-58.
93 Ibid., p. 42.

94 Ibid., p. 2.

95 Cunningham, op. cit., note 89 above, p. 139. 
The antipathy towards Koch felt by many Anglo-Indians was motivated to a large part by a patriotic disdain for Germany. Anglo-Indians found it acutely embarrassing that a German should be responsible for discovering the cause of a disease that the British colonial authorities were struggling to contain. Pettenkofer, too, was not immune from such criticisms. Harrison has pointed out that Kenneth McLeod, editor of the Indian Medical Gazette between 1871 and 1892, was resentful of Pettenkofer's influence in India. ${ }^{96}$ But whereas Pettenkofer had achieved fame in the pre-unification era, Koch's discovery coincided with the burgeoning nationalism of the Reich. Koch was fêted as a national hero following his isolation of the comma bacillus. On his return to Berlin he was honoured by the state with medals, money, and banquets. Koch was thus seen as being closely associated with the imperial authorities in a way that the Bavarian Pettenkofer was not. Anglo-Indians were more acutely aware of his nationality and the victory which Germany was claiming on account of his work.

By denying the eligibility of Koch to be making discoveries in India at all, AngloIndians were not only defending their terrain against German scientific expansionism, they were also setting themselves up as the only legitimate conduits of Western science in India. Arnold has posited that colonial science

repeatedly pitted the expertise and understanding of the old India hand against the brash universalizing of metropolitan science. The argument was repeatedly made that only those who knew India from long experience could possibly pronounce upon the nature of its diseases and its medical or public health requirements, or were in a position to understand how cultural and environmental factors might affect the practical application of Western medical science. ${ }^{97}$

The Indian soil, claimed by the colonizing British, had also been appropriated as their scientific territory. They alone possessed the requisite knowledge of the land to achieve scientific success. Only they could accommodate themselves and their science to the peculiarities of the Indian climate and culture.

The "special" nature of India was frequently cited as a means of disqualifying politically unacceptable theories such as Koch's. Joseph Fayrer thought that "cholera may have different modes of working in India from those in Europe. It is so with other epidemics." 98 Even germ-theorists such as E H Hankin (1865-1939), a governmental bacteriologist in the 1890 s, conceded that "It must be admitted that there are certain difficulties in the way of accepting the cholera microbe as the cause of the disease in India. Some have thought that in India it must travel in ways unknown to European observers."99

The accusation levelled against Koch, that he was merely a tourist unable to comprehend the mysteries of the subcontinent, surfaced again when Waldemar Haffkine (1860-1930) tried to gather support for his vaccination programmes in the $1890 \mathrm{~s} .{ }^{100} \mathrm{At}$ the end of his 1894 paper, Cunningham discussed the potential of Haffkine's cholera vaccine. Early in 1892, Cunningham had sent a particularly virulent strain of comma bacilli to Paris, to aid Haffkine in his search for an effective vaccine. ${ }^{101}$ But this

96 Harrison, op. cit., note 4 above, p. 114.

97 Arnold, op. cit., note 4 above, p. 19.

98 Fayrer J, 'Presidential address at the epidemiological Society, 5th November 1879', in op. cit., note 17 above, pp. 41-56, on p. 53.

99 E H Hankin, Cholera in Indian cantonments and how to deal with it, Allahabad, Pioneer Press, 1895, p. 3.
100 G H Bornside, 'Waldemar Haffkine's cholera vaccines and the Ferran-Haffkine priority dispute', J. Hist. Med. Allied Sci., 1982, 37: 399-422, p. 409.

101 I Löwy, 'From guinea pigs to man: the development of Haffkine's anticholera vaccine', J. Hist. Med. Allied Sci., 1992, 47: 270-308, p. 282. 


\section{D Cunningham and the Aetiology of Cholera}

acknowledgement did not imply that Cunningham anticipated its being successful or that he would view any progress as a vindication of the aetiological role of the comma bacillus. According to Cunningham, the vaccine would have no power over the specific cholera poison entering the intestinal tract, and therefore could not affect the prevalence of the disease. It might, he conceded, affect the behaviour of the naturally occurring intestinal comma bacilli whose abnormal multiplication caused the secondary symptoms of cholera. This would lessen the intensity of the second phase of the disease, and perhaps reduce the mortality rate.

Cunningham interpreted Haffkine's vaccine not as a specific experiment of germ theory but as part of an overall public health response to cholera. Thus the vaccine would "not in any way prevent the occurrence of cases of the disease, but it will modify their character in a fashion similar to that which ... hygienic improvements in a locality may do." 102 This conclusion was not lost on Hankin, who saw it as evidence that Cunningham's "attitude towards the cholera microbe is not so completely sceptical as was once the case." 103

\section{7: Cunningham's Last Bow}

Cunningham's last contribution to cholera research was published in Scientific Memoirs in 1897 , the year of his retirement. ${ }^{104} \mathrm{His}$ research had revealed the existence of further species of comma bacilli occurring in association with cholera, and the paper opened with a thorough description of their cultural characteristics. Following this was a description of comma bacilli found in the intestines of some unfortunate fish.

in ... September 1895 a fatal epidemic occurred among a number of gold-fish which had for several years lived, apparently in perfect health, in a large basin of water in the verandah of a house in Calcutta, and in the course of a few days proved fatal to all of them but one. This one was removed to another basin and is still alive and healthy up to the present time-more than a year later. ${ }^{105}$

For Cunningham no area of Indian life was too mundane to be brought into the debate, especially if this widening of the laboratory to encompass the entire nation yielded evidence in support of his views. The diseased fish were dissected and comma bacilli found in their intestines. Further dissections revealed the presence of such bacilli in the intestines of healthy fish as well. This discovery was significant in that it added to antiKochian assertions that the cholera vibrio was normally present in healthy individuals and in the environment without the disease being present. This finding was considered significant enough to gain a mention in Leonard Rogers' cholera tract of 1911, long after the debate had been closed in Koch's favour. ${ }^{106}$ Cunningham's discussion began in characteristic style, with yet another attack on Koch for failing to find more than one species of comma bacillus. When in Calcutta Koch had either been "profoundly ignorant of vibrionic schizomycetes as a group" or had missed the extra species isolated by Cunningham "owing to his brief and limited local experience". 107

102 Cunningham, op. cit., note 92 above, p. 56.

103 Hankin, op. cit., note 99 above, p. 5.

104 D D Cunningham, 'Choleraic and other commas: on the influence of certain conditions in determining morphological variations in vibrionic organisms', Sci. Mem., 1897, 10: 1-28.
105 Ibid., p. 6. Spot the localist response-removal to a clean environment!

106 L Rogers, Cholera and its treatment, Oxford University Press, 1911, p. 67.

107 Cunningham, op. cit., note 104 above, p. 16. 


\section{Jeremy D Isaacs}

Cunningham did concede, however, that Koch had been the first observer to draw attention to a special relationship existing between the occurrence of cholera and the presence of vibrionic organisms in the digestive tract. This remark, in itself quite significant, was followed by an even more unexpected statement in which fifteen years of struggle against Koch appeared to have taken their toll.

The accumulation of evidence, indicative of the . . . almost constant association of vibrionic organisms with the choleraic condition, renders it more and more difficult to regard the phenomenon as a purely fortuitous one, or one solely dependent on alterations in the nature of the intestinal contents ... All that I am now prepared to grant is, that the normal presence of vibrionic organisms of various species as a predominant and characteristic feature of the contents of the intestinal tract during the choleraic condition does suggest the probability that vibriones as a group do really hold causal relation to the development of that condition. ${ }^{108}$ [My emphasis.]

This concession completely contradicted the conclusions of his previous paper in allowing that the bacteria were themselves responsible for "convert[ing] the intestinal contents into a medium specially favouring their multiplication." 109

Cunningham's last remaining objection to Koch was that the entry of comma bacilli into the intestinal tract was not in itself sufficient to cause the disease. In producing evidence supporting this hypothesis, Cunningham revealed an interesting and peculiarly colonial form of experimental protocol.

Actual experimental evidence on the effects of the ingestion of fresh choleraic dejecta is naturally not forthcoming, but when I first became acquainted with the General Hospital in Calcutta, the old head-sweeper there was always willing to earn a rupee by partaking of a dose, and certainly appeared to suffer from no ill-effects from the treatment, and judging by the habits of the class to which he belonged, there can no reasonable question that members of the latter must, during any period of prevalence of cholera, be constantly liable to carry out similar experiments, casually and involuntarily, with equal impunity. ${ }^{110}$

Unlike Pettenkofer, Cunningham did not appear to have regarded himself or his fellow Anglo-Indians as appropriate subjects for such a dangerous auto-experiment. ${ }^{111}$

Cunningham now identified the true cause of the disease as a toxin manufactured by the cholera vibrio. This poison was, however, produced only when the bacillus was in the external environment, and not when it was present in the intestine. Cunningham attempted to show that it was the ingestion of the externally produced toxin which caused the disease, and not the arrival of cholera bacilli in the gut. In support of this theory, Cunningham invoked a series of botanical analogies. The bacterium could not initiate

108 Ibid., p. 18.

109 Ibid.

110 Ibid., p. 19.

111 A more radical means of procuring

"volunteers" for similar experiments was suggested by Surgeon-General Cornish, President of the South India branch of the BMA. He proposed "that a small portion of the $[300-400]$ annual victims of the hangman might be spared the final execution of the judicial sentence ... to subject themselves to scientific experimentation, in reference to the artificial production of cholera." "An address on cholera enquiry', IMG, 1885, 20: 169-72, p. 169. However, the occasional deliberate ingestion of contaminated material by sceptical Anglo-Indians is reported in the medical press. For example, "Dr Weir, the health officer of Bombay, had found 'bacilli analogous to the bacilli discovered by Koch' in the well water used by persons suffering from a cholera outbreak. Much against Dr. Weir's expressed wish Dr. Balfour of Bombay drank a large quantity of the suspected water containing the bacilli without any positive result." 'Current medical topics', IMG, 1884, 19: 205. 


\section{D Cunningham and the Aetiology of Cholera}

cholera when introduced into the intestines in the same way that swallowing yeast would not bring about a state of alcoholic intoxication. Similarly, the cholera bacillus need not necessarily be present in the intestines of a cholera victim since it was entirely possible to consume alcohol and become intoxicated without yeast being present.

Despite his concessions to germ theory, Cunningham's final formulation of his aetiological position retained a strong localist element. Thus local conditions might affect the growth and multiplication of the cholera bacillus, and favour the entry of bacilli or their products into the bodies of the resident population. More importantly, environmental elements might affect the capacity of the cholera vibrio to produce its toxin. Here, Cunningham drew another parallel from his botanical work, citing Indian hemp as a plant which would yield a "toxic resin" only when cultivated under certain conditions. ${ }^{112}$

The strength of Cunningham's theory was that it had a degree of explanatory power not possessed by Koch's doctrine. Cunningham continually disputed Koch's theory because it simply could not account for the epidemiological characteristics of the disease. In addition, Cunningham opposed Koch because in his experience artificial introduction of comma bacilli to the intestine rarely induced cholera, and because he had seen cases of the disease in which comma bacilli were absent. Similarly, the number of comma bacilli found in the intestines did not necessarily correlate with the severity of the disease. The aetiological mechanism proposed by Cunningham could account for these results, even if he could not provide any evidence of its operation in the field, or of the existence of his putative toxin.

Throughout the early 1890s, Cunningham kept up his academic duties, published extensively on pathological and botanical issues, and was chairman of the Calcutta Zoological Garden, in whose grounds he helped to establish a laboratory. He acted as an informal adviser to government officials and private cultivators worried about parasites attacking their crops. His value to the state was recognized when Lord Dufferin appointed him honorary-surgeon to the Viceroy. But the constant drudgery of government-sponsored cholera research on top of his other commitments eventually took its toll. His health deteriorated and in 1897 he became seriously ill and had to be invalided to Europe. He never fully recovered, and was forbidden to return to India, settling instead in Torquay where he devoted himself to writing and tending to his garden. ${ }^{113}$

\section{Leaving the Debate and Being Left Out of the Historiography}

Although Cunningham's published work of the 1890s revealed a constantly shifting aetiological standpoint, veering from extreme anti-contagionism to a modified germ theory, there were constant elements in his approach. His insistence on the primacy of local conditions never wavered and he remained essentially true to Pettenkofer's theories while having the courage to offer modifications. Similarly, he continually held that Koch

\footnotetext{
112 Cunningham had been working on Indian hemp in the early 1890s for the Indian Hemp Drugs Commission. Experiments conducted on a Rhesus monkey "subjected to frequent inhalation of the smoke of ganja for a continuous period of more than eight months" appeared to indicate "that the habitual inhalation of the smoke of ganja may under some
}

circumstances be positively beneficial." $29 t h$ ARSCGI (for 1892), published 1894, p. 200.

113 An extensive account of Cunningham's later life, although it passes over much of his cholera research, can be found in Roy. Soc. Proc. Series B, 1917, 89: 15-20. 
had missed several species of comma bacilli. He worked tirelessly to find ever greater numbers of distinct species of "choleraic comma-bacilli" meticulously describing their appearance and cultural characteristics.

However, despite his fastidious approach, towards the end of his career Cunningham found it increasingly difficult to keep up with rapidly moving advances in theory and methodology. Specially trained bacteriologists such as Hankin were brought to India in the 1890 s to advise an increasingly receptive government on policy matters. With his modern training, which included a period in Koch's Institute in Berlin, Hankin was not slow to identify weaknesses in Cunningham's work. ${ }^{114}$ Cunningham had used his failure to find cholera vibrios in cases of the disease to undermine Koch's theory. Hankin was unimpressed.

... most of Cunningham's work on the subject is weakened by the fact that he worked without the advantage of the peptone method. It is only by means of this recently discovered method that it has become possible to detect the cholera microbe with certainty in substances in which it is only present in traces. ${ }^{115}$

The peptone method involved preparing colonies of cholera bacilli on a plate injected with a one per cent peptone solution. This created a medium selective for the growth of comma bacilli at the expense of contaminating bacteria. ${ }^{116}$

This was not the only methodological weakness which fellow Anglo-Indians identified in Cunningham's research. Reviewing his work in 1894, W J Simpson, McLeod's successor as editor of the Indian Medical Gazette, found it

impossible to agree with Dr. Cunningham in his conclusions that the morphological and physiological properties of the thirteen commas which he describes constitute such differences as to entitle them to be placed in nature as thirteen different species ... until it is shown that these thirteen commas have different pathogenic properties it is unlikely that Professor Cunningham's views will find acceptance. ${ }^{117}$

Simpson cited numerous examples of other bacteria whose form often differed from that classically described but whose ability to cause disease was unchanged. Indeed, he positively crowed with delight when, later in 1894, Elie Metchnikoff succeeded in showing that under certain conditions comma bacilli could permanently alter their shape yet keep their pathogenic abilities. ${ }^{118}$

A further blow was dealt to Cunningham when Koch and his assistants succeeded in generating cholera in an animal model. Using guinea pigs, Koch alkalinised the gastric contents with sodium carbonate and abolished peristalsis with opium. His animals died with cholera-like symptoms forty-eight hours after the introduction of cholera vibrios to the stomach. 119

Despite the widespread acceptance of Koch's bacillus in Europe, particularly following the Hamburg epidemic of 1892, many Anglo-Indians of Cunningham's generation

\footnotetext{
$114 \mathrm{M} \mathrm{W}$ Weatherall, 'Scientific medicine and the medical sciences in Cambridge, 1851 to 1939', $\mathrm{PhD}$ thesis, University of Cambridge, 1994, pp. 82-5.

115 Hankin, op. cit., note 99 above, p. 5.

116 R Muir and J Ritchie, Manual of bacteriology, Edinburgh and London, Young J Pentland, 1897, p. 399.
}

\footnotetext{
117 'Professor Cunningham's recent observations on the comma bacillus', IMG, 1894, 29: 170-80, p. 180.

118 'Varieties of the comma bacilus', ibid., p. 421.

119 M V Ball, Essentials of bacteriology, London, Henry Kimpton, 1894, p. 110.
} 


\section{D Cunningham and the Aetiology of Cholera}

remained sceptical. Chief among Cunningham's allies in continuing to condemn Koch's theory and its consequences was Joseph Fayrer. In 1893, in a lecture on cholera to the Queen's Jubilee Nurses, he announced that "of the true nature of its cause, I fear we must still be regarded as, to a great extent, ignorant". ${ }^{120}$

Moreover, the increasing acceptance of Koch's comma bacillus as the aetiological agent in cholera had yet to produce a therapeutic breakthrough. Some physicians had begun administering crude antiseptic agents such as carbolic acid, creosote and compounds of arsenic to their patients in the hope that they might have some antibacterial effect. ${ }^{121}$ Almost as soon as they came into use, however, Anglo-Indian doctors were dismissing such drugs as worse than useless. "In consequence of Dr. Koch's theories of cholera," wrote an aggrieved Indian army surgeon in 1893,

a large school of therapeutics has arisen, who believe that the only method of treating cholera is by disinfecting the intestines ... The results of this treatment [have] been most disastrous. In being the cause of the origin of this school Dr. Koch's theory has already ... produced a large and irreparable amount of mischief. ${ }^{122}$

In fact, far from vindicating Koch's comma bacillus as the cause of cholera, the crude use of antiseptic agents actually gave succour to those who opposed this explanation. The Indian sanitary establishment, however, was warming to Koch's bacillus. Contrary to popular fears, Koch was not a proponent of large scale quarantine but an advocate of improved public health and the avoidance of polluted drinking water. ${ }^{123}$ Thus Sanitary Commissioner James Cleghorn announced in his 1895 report that "the practical certainty of the truth of the theory of microbic infection should be used as the basis of the next revision of the rules regarding the measures to be adopted on the outbreak of cholera."124

Cunningham's contribution was, however, considered significant by many AngloIndian doctors, if only because he had taken the shine off Koch's theories. In 1911 Rogers still claimed that Cunningham's "careful and prolonged researches" had "conclusively proved that the comma bacilli of cholera differed widely from one another in morphology and cultural characters and were very far from being a single defined form as originally described by Koch."125 However, Rogers conceded that Metchnikoff had proved Cunningham wrong by demonstrating that the cholera bacilli were "pleomorphic and cannot be separated into distinct species by their morphological characters as Cunningham originally held." 126

Cunningham's obituarist in the British Medical Journal lamented that his investigations into the various theories had proved inconclusive, and that "Their outcome being of a negative nature, much of his work was destructive, and the critical habit thus acquired probably accounts for the fact that no positive discovery of importance can be associated

120 J Fayrer, 'A lecture delivered at St. Katherine's Royal Hospital to the Queen's Jubilee Nurses, at the request of the Council of the Institute on Nursing in cholera, and how to deal with it as first aid, 4th May 1893 ', in op. cit., note 17 above, vol. 2, pp. 115-35, on p. 121 .

121 R Bartholow, Cholera: its causes, symptoms, pathology, and treatment, Philadelphia, Lea, 1893, p. 94.
122 A J Wall, Asiatic cholera: its history, pathology, and modern treatment, London, $\mathrm{H} \mathrm{K}$ Lewis, 1893, p. 118.

123 Hume, op. cit., note 11 above, pp. 102, 104-5.

124 31st ARSCGI (for 1895), published 1896, p. 181 .

${ }_{125}$ Rogers, op. cit., note 106 above, p. 54.

126 Ibid., p. 58. 
with his name." 127 It was not so much that Cunningham's results were negative; rather, he was constrained by the programme which he was set by the Sanitary Commissioner. In the wake of Koch's discovery, Cunningham's laboratory and the journal in which he published his findings were set up in a reactionary move by a defensive sanitary establishment. The onus was on Cunningham to prove Koch wrong in the first instance, rather than initiate new areas of research. Thus, the possibility of scientific progress coming from Cunningham's work was limited by the political context in which he worked.

It is, therefore, hardly surprising that Cunningham should have been written out of the cholera story. Modern scientific accounts of the disease make no reference to Cunningham despite frequently discussing the work of Koch and Haffkine in the 1880s and 1890s. ${ }^{128}$ Historians such as Ramasubban and Arnold have only briefly referred to Cunningham in their consideration of the political discourse surrounding disease in colonial India. ${ }^{129}$ Only Harrison has discussed Cunningham's work at any length. His purpose in doing this, however, is to demonstrate how scientific work informed sanitary policy, rather than to explore the significant features of Cunningham's research programme.

Cunningham has also been mentioned merely to expose the intransigence of colonial doctors in the face of the "progressive" advances offered by Koch. Jaggi, for example, claims that "the prejudiced and unscientific attitude of the I.M.S. officers was essentially responsible for making an ass of themselves in connection with the discovery of the causative agent of cholera." ${ }^{130}$ A biased historiography, and a cursory examination of primary literature, may give the impression that Anglo-Indian doctors did have their heads buried in the sand, refusing to accept the truths that flowed from Koch's pen. In fact colonial medical officers felt that they were closer to the "Indian truth" than Koch, while conceding that in the European arena, and in the laboratory, Kochian germ theory was harder to dispute.

\section{Conclusion}

In this paper I have attempted to shift discussion of laboratory medicine from the unidirectional notion of "revolution" to a more detailed consideration of why laboratories are used in particular ways at particular times. I broadly dissected Cunningham's cholera research into two periods: that done prior to Koch's discovery in 1884, and that performed in its wake. I explored the political considerations which shaped his research in these two periods. His early work, despite its inception by Parkes, became, in the hands of $\mathrm{J} \mathbf{M}$ Cuningham, a tool for the legitimation of colonial sanitary policy. His later research was commissioned by a defensive Anglo-Indian establishment as a reaction against Koch rather than as a means of developing original ideas. Cunningham could not, therefore, have achieved success so long as he worked from within the confines of the "Commissioner's laboratory".

127 Br. med. J., 1915, i: 141.

128 R Pollitzer, Cholera, Geneva, WHO, 1959, pp. 99-101, 294-5; D Barua and W B Greenough III (eds), Cholera, New York, Plenum Medical Book Co., 1992, pp. 155-7, 286-7.
129 Ramasubban, op. cit., note 9 above, pp. 45-6; Arnold, op. cit., note 4 above, p. 144; Harrison, op. cit., note 4 above, pp. 113-15.

130 Jaggi, op. cit., note 6 above, p. 63. 


\section{D Cunningham and the Aetiology of Cholera}

In each of these periods I also explored the necessity, in the colonial context, of uniting laboratory technique with local conditions. Initially, Cunningham carried out his research along two semi-independent lines: searching for a cholera-fungus on the one hand and analysing environmental conditions on the other. Koch's discovery of the comma bacillus threatened this approach of searching for answers in both the laboratory and the field. Yet Cunningham felt that Koch had failed to acknowledge sufficiently the uniqueness of the Indian environment. As an Anglo-Indian he regarded this difficult terrain as his scientific territory. Koch, with his fleeting observations of Calcutta's cholera-prone quarters could not offer a "local science" to deal with a disease many Anglo-Indians regarded as a problem of locality. Thus in attacking Koch, Cunningham was both denying the universal applicability of Kochian bacteriology and attempting to preserve an Anglo-Indian tradition of disease investigation.

Cunningham responded to Koch by broadening the scope of his laboratory work to encompass aspects of the environment over which he, as an Anglo-Indian, could claim a unique understanding. His aetiological theories demanded an explanation for the epidemiological behaviour of any cholera-causing organism; and in his experimental work he tried to assess the viability of the cholera bacillus in the Indian soil, concluding that local conditions were the paramount factor in determining the pathogenicity of the bacterium. Cunningham thus sought to unite the essentially European culture of the laboratory with the idiosyncrasies of the Indian field. In so doing he pursued a line of enquiry the results of which are no longer of interest to our universalist medical science. Yet his work demonstrates that in the area of infectious disease, where immense change occurred in the late nineteenth century, use of the bacteriological laboratory was not sufficient to ensure success. Powerful influences within and without the laboratory could drive a scientist to support a failing doctrine, even if the revolution was in the opposite direction, which at the time, of course, it may not have appeared to be. 